Article

\title{
Highly Oxygenated Triterpenoids and Diterpenoids from Fructus Rubi (Rubus chingii Hu) and Their NF-kappa B Inhibitory Effects
}

\author{
Jiang Wan ${ }^{1,+}$, Xiao-Juan Wang ${ }^{1,+}{ }^{+}$, Nan Guo ${ }^{1}$, Xi-Ying $W_{u}{ }^{1}$, Juan Xiong ${ }^{1}$, Yi Zang ${ }^{2} \oplus$, Chun-Xiao Jiang ${ }^{3}$, \\ Bing Han ${ }^{1, *}$, Jia $\mathrm{Li}^{2, *}$ and Jin-Feng $\mathrm{Hu}^{1,3, *}$ \\ 1 Minhang Hospital \& School of Pharmacy, Fudan University, Shanghai 201199, China; \\ 18111030021@fudan.edu.cn (J.W.); 18221765046@163.com (X.-J.W.); gnguoguo@163.com (N.G.); \\ wxyifd@163.com (X.-Y.W.); jxiong@fudan.edu.cn (J.X.) \\ 2 State Key Laboratory of Drug Research, Shanghai Institute of Materia Medica, Chinese Academy of Science, \\ Shanghai 201203, China; yzang@simm.ac.cn \\ 3 Institute of Natural Medicine and Health Products, School of Advance Study, Zhejiang Provincial Key \\ Laboratory of Plant Ecology and Conservation, Taizhou University, Taizhou 318000, China; \\ jiangchx15@tzc.edu.cn \\ * Correspondence: hbshcn@163.com (B.H.); jli@simm.ac.cn (J.L.); jfhu@fudan.edu.cn (J.-F.H.); \\ Tel.: +86-21-51980172 (J.-F.H.) \\ + These authors contributed equally to this work.
}

\section{check for} updates

Citation: Wan, J.; Wang, X.-J.; Guo, N.; Wu, X.-Y.; Xiong, J.; Zang, Y.; Jiang, C.-X.; Han, B.; Li, J.; Hu, J.-F. Highly Oxygenated Triterpenoids and Diterpenoids from Fructus Rubi (Rubus chingii $\mathrm{Hu}$ ) and Their NF-kappa B Inhibitory Effects. Molecules 2021, 26, 1911. https://doi.org/10.3390/ molecules 26071911

Academic Editor: Vassilios Roussis

Received: 21 February 2021

Accepted: 24 March 2021

Published: 29 March 2021

Publisher's Note: MDPI stays neutral with regard to jurisdictional claims in published maps and institutional affiliations.

Copyright: (c) 2021 by the authors. Licensee MDPI, Basel, Switzerland. This article is an open access article distributed under the terms and conditions of the Creative Commons Attribution (CC BY) license (https:// creativecommons.org/licenses/by/ $4.0 /)$.

\begin{abstract}
During a phytochemical investigation of the unripe fruits of Rubus chingii Hu (i.e., Fructus Rubi, a traditional Chinese medicine named "Fu-Pen-Zi"), a number of highly oxygenated terpenoids were isolated and characterized. These included nine ursane-type (1, 2, and 4-10), five oleanane-type $(3,11-14)$, and six cucurbitane-type (15-20) triterpenoids, together with five entkaurane-type diterpenoids (21-25). Among them, $(4 R, 5 R, 8 R, 9 R, 10 R, 14 S, 17 S, 18 S, 19 R, 20 R)-2,19 \alpha, 23-$ trihydroxy-3-oxo-urs-1,12-dien-28-oic acid (rubusacid A, 1), $\left(2 R^{*}, 4 S^{*}, 5 R^{*}, 8 R^{*}, 9 R^{*}, 10 R^{*}, 14 S^{*}, 17 S^{*}\right.$, $\left.18 S^{*}, 19 R^{*}, 20 R^{*}\right)-2 \alpha, 19 \alpha, 24$-trihydroxy-3-oxo-urs-12-en-28-oic acid (rubusacid B, 2), $(5 R, 8 R, 9 R, 10 R$, $14 S, 17 R, 18 S, 19 S)$-2,19 $\alpha$-dihydroxy-olean-1,12-dien-28-oic acid (rubusacid C, 3), and (3S,5S,8S,9R, $10 S, 13 R, 16 R)-3 \alpha, 16 \alpha, 17$-trihydroxy-ent-kaur-2-one (rubusone, 21) were previously undescribed. Their chemical structures and absolute configurations were elucidated on the basis of spectroscopic data and electronic circular dichroism (ECD) analyses. Compounds $\mathbf{1}$ and $\mathbf{3}$ are rare naturally occurring pentacyclic triterpenoids featuring a special $\alpha, \beta$-unsaturated keto-enol (diosphenol) unit in ring A. Cucurbitacin B (15), cucurbitacin D (16), and 3 $\alpha, 16 \alpha, 20(R), 25$-tetrahydroxy-cucurbita-5,23dien-2,11,22-trione (17) were found to have remarkable inhibitory effects against NF- $\kappa \mathrm{B}$, with $\mathrm{IC}_{50}$ values of $0.08,0.61$, and $1.60 \mu \mathrm{M}$, respectively.
\end{abstract}

Keywords: Rubus chingii Hu; Rosaceae; triterpenoids; rubusacids; diterpenoids; rubusone; NF- $\kappa \mathrm{B}$

\section{Introduction}

The Rubus genus (family Rosaceae) is large and diverse (with about 700 species distributed worldwide), and Flora of China lists 139 species as endemic to China [1]. They are usually deciduous or semi-evergreen perennial herbs or shrubs, which are often spiny, with a characteristic fruit formed as a head of one-seeded drupelets. The unripe fruits of Rubus chingii $\mathrm{Hu}$ (Fructus Rubi, referred to as "Fu-Pen-Zi" in Chinese, bogbun-ja in Korean, and gosho-ichigo in Japanese) have been widely used as a herb tonic for the treatment of various diseases, mainly associated with kidney deficiency, in East Asian countries [2,3]. As a top-grade traditional Chinese medicine, Fructus Rubi was recorded in one of the earliest collections in the Pharmacopeia of the People's Republic of China [4]. The phytochemistry and pharmacology of $R$. chingii have recently been well-documented by two review articles [2,5], and both triterpenoids and diterpenoids are 
encountered in the fruits. Modern pharmacological studies have revealed that the chemical components from Fructus Rubi exhibit a broad spectrum of bioactivities, such as being anti-aging [6], anti-cancer [7], anti-oxidant [7,8], and anti-diabetic [9]. With the aim of obtaining more structurally interesting and bioactive naturally occurring triterpenoids and diterpenoids [10-12], a phytochemical investigation of a commercially available sample of Fructus Rubi was carried out, which resulted in the isolation of three new highly oxygenated pentacyclic triterpenoids (1-3) and one new ent-kaurane-type diterpenoid (21), along with 21 related known terpenoid compounds (4-20 and 22-25) (Figure 1). Herein, the isolation, structural elucidation, and NF- $\kappa$ B inhibitory activities of these compounds are reported.

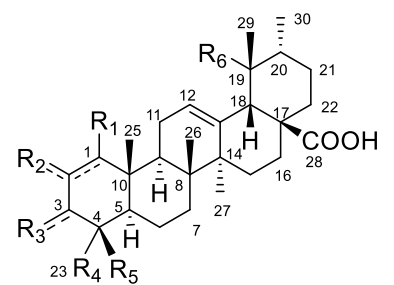

$1 \mathrm{R}_{1}=\mathrm{HR}_{2}=\mathrm{R}_{6}=\mathrm{OH} \mathrm{R}_{3}=\mathrm{OR} \mathrm{R}_{4}=\mathrm{CH}_{2} \mathrm{OH} \mathrm{R}_{5}=\mathrm{CH}_{3} \Delta^{1}$

$2 \mathrm{R}_{1}=\mathrm{H} \mathrm{R}_{2}=\alpha-\mathrm{OH} \mathrm{R} \mathrm{R}_{3}=\mathrm{OR}_{4}=\mathrm{CH}_{3} \mathrm{R}_{5}=\mathrm{CH}_{2} \mathrm{OH} \mathrm{R}=\mathrm{OH}$

$4 \mathrm{R}_{1}=\mathrm{HR}_{2}=\mathrm{R}_{6}=\mathrm{OHR} \mathrm{R}_{3}=\mathrm{OR} \mathrm{R}_{4}=\mathrm{R}_{5}=\mathrm{CH}_{3} \Delta^{1}$

$5 \mathrm{R}_{1}=\mathrm{H} \mathrm{R}_{2}=\mathrm{R}_{3}=\alpha-\mathrm{OH} \mathrm{R}_{4}=\mathrm{R}_{5}=\mathrm{CH}_{3} \mathrm{R}_{6}=\mathrm{OH}$

$6 \mathrm{R}_{1}=\mathrm{R}_{6}=\mathrm{H} \mathrm{R}_{2}=\mathrm{R}_{3}=\alpha-\mathrm{OH} \mathrm{R} \mathrm{R}_{4}=\mathrm{CH}_{2} \mathrm{OH} \mathrm{R} \mathrm{R}_{5}=\mathrm{CH}_{3}$

$7 \mathrm{R}_{1}=\mathrm{HR}_{2}=\alpha-\mathrm{OH} \mathrm{R} \mathrm{R}_{3}=\mathrm{OR}_{4}=\mathrm{R}_{5}=\mathrm{CH}_{3} \mathrm{R}_{6}=\mathrm{OH}$

$8 \mathrm{R}_{1}=\mathrm{HR}_{2}=\alpha-\mathrm{OH} \mathrm{R} \mathrm{R}_{3}=\beta-\mathrm{OH} \mathrm{R} \mathrm{R}_{4}=\mathrm{CH}_{3} \mathrm{R}_{5}=\mathrm{CH}_{2} \mathrm{OH} \mathrm{R} \mathrm{R}_{6}=\mathrm{OH}$

$9 \mathrm{R}_{1}=\mathrm{R}_{3}=\beta-\mathrm{OH} \mathrm{R}_{2}=\mathrm{O} \quad \mathrm{R}_{4}=\mathrm{R}_{5}=\mathrm{CH}_{3} \mathrm{R}_{6}=\mathrm{OH}$

$10 \mathrm{R}_{1}=\mathrm{H} \mathrm{R}_{2}=\mathrm{O} \mathrm{R}_{3}=\beta-\mathrm{OH} \mathrm{R}_{4}=\mathrm{R}_{5}=\mathrm{CH}_{3} \mathrm{R}_{6}=\mathrm{OH}$

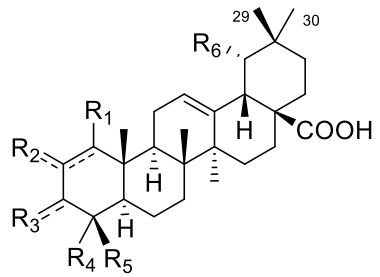

$3 \mathrm{R}_{1}=\mathrm{HR}_{2}=\mathrm{R}_{6}=\mathrm{OHR} \mathrm{R}_{3}=O \mathrm{R}_{4}=\mathrm{R}_{5}=\mathrm{CH}_{3} \Delta^{1}$

$11 \mathrm{R}_{1}=\mathrm{H} \mathrm{R}_{2}=\mathrm{R}_{3}=\alpha-\mathrm{OH} \mathrm{R}_{4}=\mathrm{CH}_{2} \mathrm{OH} \mathrm{R}_{5}=\mathrm{CH}_{3} \mathrm{R}_{6}=\mathrm{OH}$

$12 \mathrm{R}_{1}=\mathrm{R}_{6}=\mathrm{HR}_{2}=\mathrm{R}_{3}=\alpha-\mathrm{OH} \mathrm{R} \mathrm{R}_{4}=\mathrm{CH}_{2} \mathrm{OH} \mathrm{R} \mathrm{R}_{5}=\mathrm{CH}_{3}$

$13 \mathrm{R}_{1}=\mathrm{H} \mathrm{R}_{2}=\alpha-\mathrm{OH} \mathrm{R}_{3}=\beta-\mathrm{OH} \mathrm{R}_{4}=\mathrm{R}_{5}=\mathrm{CH}_{3} \mathrm{R}_{6}=\mathrm{OH}$

$14 \mathrm{R}_{1}=\mathrm{H} \mathrm{R}_{2}=\alpha-\mathrm{OH} \mathrm{R}=\beta-\mathrm{OH} \mathrm{R}_{4}=\mathrm{CH}_{3} \mathrm{R}_{5}=\mathrm{CH}_{2} \mathrm{OH} \mathrm{R} \mathrm{R}_{6}=\mathrm{OH}$

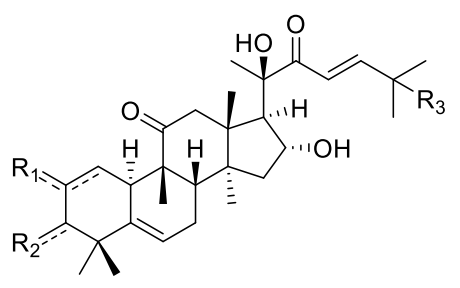

$$
\begin{aligned}
& 15 \mathrm{R}_{1}=\beta-\mathrm{OH} \mathrm{R}_{2}=\mathrm{OR} \mathrm{R}_{3}=\mathrm{OAC} \\
& 16 \mathrm{R}_{1}=\beta-\mathrm{OH} \mathrm{R}_{2}=\mathrm{O} \mathrm{R}_{3}=\mathrm{OH} \\
& 17 \mathrm{R}_{1}=\mathrm{O} \mathrm{R}_{2}=\alpha-\mathrm{OH} \mathrm{R}_{3}=\mathrm{OH} \\
& 18 \mathrm{R}_{1}=\mathrm{R}_{3}=\mathrm{OH} \mathrm{R}_{2}=\mathrm{O} \Delta^{1} \\
& 19 \mathrm{R}_{1}=\alpha-\mathrm{OH} \mathrm{R}_{2}=\mathrm{O} \mathrm{R}_{3}=\mathrm{OAC} \\
& 20 \mathrm{R}_{1}=O \mathrm{R}_{2}=\beta-\mathrm{OH} \mathrm{R}_{3}=\mathrm{OAC}
\end{aligned}
$$

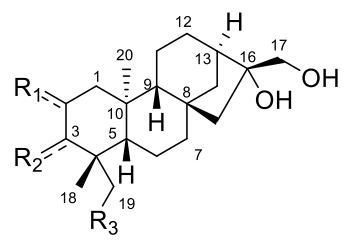

$21 \mathrm{R}_{1}=\mathrm{O} \mathrm{R}_{2}=\alpha-\mathrm{OH} \mathrm{R}_{3}=\mathrm{H}$

$22 \mathrm{R}_{1}=\mathrm{HR}_{2}=\beta-\mathrm{OH} \mathrm{R}_{3}=\mathrm{OAc}$

$23 \mathrm{R}_{1}=\mathrm{R}_{3}=\mathrm{HR}_{2}=\mathrm{O}$

$24 \mathrm{R}_{1}=\mathrm{R}_{3}=\mathrm{H} \mathrm{R}_{2}=\beta-\mathrm{OH}$

$25 \mathrm{R}_{1}=\mathrm{HR}_{2}=\mathrm{O} \mathrm{R}_{3}=\mathrm{OH}$

Figure 1. Chemical structure of triterpenoids (1-20) and diterpenoids (21-25).

\section{Results and Discussion}

A $70 \%$ ethanol extract of the unripe fruits of $R$. chingii $(28.0 \mathrm{~kg})$ was suspended in $\mathrm{H}_{2} \mathrm{O}$ and then partitioned successively with petroleum ether, EtOAc, and $n$-BuOH. The entire EtOAc-soluble fraction was repeatedly subjected to column chromatography (CC) over silica gel, MCI gel, Sephadex LH-20, and semi-preparative HPLC to afford 20 triterpenoids (1-20) and 5 diterpenoids (21-25) (Figure 1). By comparing the observed and reported physicochemical properties and spectroscopic data, the previously known ones were identified as fupenzic acid (4) [13], $2 \alpha, 3 \alpha, 19 \alpha$-trihydroxy-urs-12-en-28-oic acid (5) [14], $2 \alpha, 3 \alpha$,23-trihydroxy-urs-12-en-28-oic acid (6) [15], $2 \alpha, 19 \alpha$-dihydroxy-3-oxo-urs-12-en-28-oic acid (7) [16], $2 \alpha, 3 \beta, 19 \alpha, 24$-tetrahydroxyurs-12-en-28-oic acid (8) [17], $1 \beta, 3 \beta, 19 \alpha$-trihydroxy2-oxo-urs-12-en-28-oic acid (9) [18], 3 $\beta, 19 \alpha$-dihydroxy-2-oxo-urs-12-en-28-oic acid (10) [19], $2 \alpha, 3 \alpha, 19 \alpha, 23-t e t r a h y d r o x y-o l e a n-12-e n-28-o i c ~ a c i d ~(11) ~[20], 2 \alpha, 3 \alpha, 23-t r i h y d r o x y-u r s-12-e n-$ 28-oic acid (12) [21], arjunic acid (13) [22], 2 $\alpha, 3 \beta, 19 \alpha, 24$-tetrahydroxyolean-12-en-28-oic acid (14) [23], cucurbitacin B (15) [24], cucurbitacin D (16) [25], 3 $\alpha, 16 \alpha, 20(R), 25$-tetrahydroxycucurbita-5,23-dien-2,11,22-trione (17) [26], 2,16 ,20(R),25-tetrahydroxy-cucurbita-1,5,23trien-3,11,22-trione (18) [27], 25-acetoxy-2 $\alpha, 16 \alpha, 20(R)$-trihydroxy-cucurbita-5,23-dien-3,11,22- 
trione (19) [28], 25-acetoxy-3 $\beta, 16 \alpha, 20(R)$-trihydroxy-cucurbita-5,23-dien-2,11,22-trione (20) [26], $3 \beta, 16 \alpha, 17$-trihydroxy-ent-kaur-19-yl acetate (22) [29], 16 ,17-dihydroxy-ent-kaur-3-one

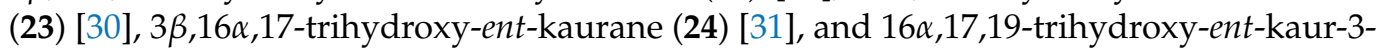
one (25) [32], respectively.

Rubusacid A (1) was obtained as a white powder. Its molecular formula was established as $\mathrm{C}_{30} \mathrm{H}_{44} \mathrm{O}_{6}$ from its HRESIMS $\left(m / z 499.3067[\mathrm{M}-\mathrm{H}]^{-}\right.$, calcd. for $\mathrm{C}_{30} \mathrm{H}_{43} \mathrm{O}_{6}$, 499.3065) and ${ }^{13} \mathrm{C}$ NMR data (Table 1). The IR spectrum exhibited characteristic absorptions for a cyclic enone $\left(1703,1644 \mathrm{~cm}^{-1}\right)$ group, which was supported by its UV absorption band at $265 \mathrm{~nm}[33,34]$. In the upfield region of the ${ }^{1} \mathrm{H}$ NMR spectrum of 1 , resonances of five tertiary methyl groups at $\delta_{\mathrm{H}} 0.90(3 \mathrm{H}, \mathrm{s}, \mathrm{Me}-26), 1.23(3 \mathrm{H}, \mathrm{s}, \mathrm{Me}-29), 1.29(3 \mathrm{H}, \mathrm{s}, \mathrm{Me}-24)$, $1.30(3 \mathrm{H}, \mathrm{s}, \mathrm{Me}-25)$, and $1.36(3 \mathrm{H}, \mathrm{s}, \mathrm{Me}-27)$, and one secondary methyl group at $\delta_{\mathrm{H}} 0.95$ $(3 \mathrm{H}, \mathrm{d}, J=7.1 \mathrm{~Hz}, \mathrm{Me}-30)$ were observed (Table 2). In addition, signals resonating at $\delta_{\mathrm{H}}$ 3.69 and $3.71\left(\mathrm{ABq}\right.$, each $\left.1 \mathrm{H}, \mathrm{d}, J=12.0 \mathrm{~Hz}, \mathrm{H}_{2}-23\right)$ for a hydroxymethylene group, and two olefinic protons at $\delta_{\mathrm{H}} 5.37(1 \mathrm{H}, \mathrm{dd}, J=3.7,3.5 \mathrm{~Hz}, \mathrm{H}-12)$ and $6.29(1 \mathrm{H}, \mathrm{s}, \mathrm{H}-1)$ were also readily distinguished. A total of 30 carbon signals, including a ketone carbonyl at $\delta_{\mathrm{C}} 200.5$ (C-3), a carboxyl carbon at $\delta_{\mathrm{C}} 182.2$ (C-28), four olefinic carbons at $\delta_{\mathrm{C}} 145.8$ (C-2), 140.4 (C-13), 129.5 (C-1), and 129.0 (C-12), and two oxygenated carbons at $\delta_{\mathrm{C}} 73.5$ (C-19) and 65.9 (C-23), were displayed in its ${ }^{13} \mathrm{C}$ NMR spectrum. The aforementioned NMR data of 1 highly resembled those of fupenzic acid (4) [13], a co-occurring ursane-type triterpenoid with an $\alpha, \beta$-unsaturated keto-enol moiety (i.e., diosphenol chromophore $[13,35,36]$ ) in ring $\mathrm{A}$. The only difference between them was that the Me-23 in 4 was hydroxylated in 1, which was confirmed by the $\mathrm{H}_{3}-24 / \mathrm{C}-23$ and $\mathrm{H}_{2}-23 / \mathrm{C}-3$ correlations (Figure 2) in its HMBC NMR spectrum. The relative configuration of $\mathbf{1}$ was determined by ROESY data analysis (Figure 3). The ROE correlation of $\mathrm{H}_{2}-23$ with $\mathrm{H}-5$, along with the absence between $\mathrm{H}_{2}-23$ and $\mathrm{H}_{3}-25$, confirmed the $\alpha$-orientation of the $23-\mathrm{CH}_{2} \mathrm{OH}$ group. Moreover, the ROE correlations of $\mathrm{H}-18$ with $\mathrm{H}-12 / \mathrm{H}-20 / \mathrm{H}_{3}-29$, and of $\mathrm{H}_{3}-29$ with $\mathrm{H}-12 / \mathrm{H}-20$ demonstrated that $\mathrm{H}-18, \mathrm{H}-20$, and $\mathrm{H}_{3}-29$ were all $\beta$-oriented, thus requiring $\mathrm{OH}-19$ in the $\alpha$-orientation. The electronic circular dichroism (ECD) spectrum of $\mathbf{1}$ exhibited Cotton effects (CEs) at $217(\Delta \varepsilon-16.3), 274(\Delta \varepsilon+13.9)$, and $330(\Delta \varepsilon-3.0) \mathrm{nm}$ (Figure S6, Supporting Information), corresponding to the $n \rightarrow \pi^{*}$ and $\pi \rightarrow \pi^{*}$ transitions of the unsaturated cyclohexanone chromophore. The ECD data of $\mathbf{1}$ were similar to those of (+)-cyrillin A [34] and sapiumic acid $\mathrm{F}$ [37], two pentacyclic triterpenoids possessing a common enone group in ring A, which then allowed the assignment of a $10 R$ configuration in 1 . Consequently, the structure of 1 was characterized as $(4 R, 5 R, 8 R, 9 R, 10 R, 14 S, 17 S, 18 S, 19 R, 20 R)-2,19 \alpha, 23$-trihydroxy-3oxo- urs-1,12-dien-28-oic acid.

Table $1 .{ }^{13} \mathrm{C}$ NMR data ${ }^{a}\left(\delta\right.$ in ppm, $150 \mathrm{MHz}$ ) of compounds 1-3 (in $\mathrm{CD}_{3} \mathrm{OD}$ ) and 21 (in $\mathrm{C}_{6} \mathrm{D}_{6}$ ).

\begin{tabular}{cccccccccc}
\hline No. & $\mathbf{1}$ & $\mathbf{2}$ & $\mathbf{3}$ & $\mathbf{2 1}$ & $\mathbf{N o .}$ & $\mathbf{1}$ & $\mathbf{2}$ & $\mathbf{3}$ & $\mathbf{2 1}$ \\
\hline 1 & 129.5 & 51.2 & 130.0 & 53.0 & 16 & 26.6 & 26.6 & 29.4 & 81.2 \\
2 & 145.8 & 71.2 & 146.0 & 210.2 & 17 & 48.7 & 49.0 & 46.7 & 66.3 \\
3 & 200.5 & 215.4 & 202.4 & 82.8 & 18 & 55.2 & 55.1 & 45.3 & 29.6 \\
4 & 51.6 & 56.4 & 45.5 & 45.6 & 19 & 73.5 & 73.6 & 82.4 & 16.6 \\
5 & 55.8 & 60.2 & 55.2 & 54.0 & 20 & 43.1 & 43.1 & 36.1 & 18.4 \\
6 & 19.9 & 20.9 & 20.2 & 20.4 & 21 & 27.3 & 27.3 & 28.6 & \\
7 & 34.6 & 34.4 & 33.7 & 41.5 & 22 & 38.9 & 38.9 & 34.0 & \\
8 & 41.7 & 41.2 & 41.3 & 45.1 & 23 & 65.9 & 20.1 & 22.2 & \\
9 & 44.6 & 48.5 & 44.7 & 55.6 & 24 & 22.0 & 66.0 & 28.0 & \\
10 & 39.4 & 39.0 & 39.7 & 45.2 & 25 & 20.5 & 17.6 & 20.0 & \\
11 & 24.9 & 24.8 & 24.3 & 18.8 & 26 & 17.8 & 17.3 & 18.0 & \\
12 & 129.0 & 128.9 & 124.5 & 26.1 & 27 & 24.8 & 25.0 & 25.1 & \\
13 & 140.4 & 140.2 & 145.0 & 44.6 & 28 & 182.2 & 182.2 & 182.3 & \\
14 & 42.9 & 42.7 & 43.0 & 36.8 & 29 & 27.0 & 27.1 & 28.1 & \\
15 & 29.5 & 29.6 & 29.5 & 52.9 & 30 & 16.6 & 16.6 & 25.1 & \\
\hline Assignments
\end{tabular}

a Assignments were made by a combination of 1D and 2D NMR experiments. 
Table 2. ${ }^{1} \mathrm{H}$ NMR data ${ }^{a}$ ( $\delta$ in ppm, $J$ values in $\mathrm{Hz}, 600 \mathrm{MHz}$ ) of $1-3$ in $\mathrm{CD}_{3} \mathrm{OD}$.

\begin{tabular}{|c|c|c|c|}
\hline No. & 1 & 2 & 3 \\
\hline $1 \alpha$ & $6.29 \mathrm{~s}$ & $1.17 \mathrm{dd}(12.7,12.5)$ & $6.27 \mathrm{~s}$ \\
\hline $1 \beta$ & & $2.31 \mathrm{dd}(12.5,6.6)$ & \\
\hline 2 & & $4.62 \mathrm{dd}(12.7,6.6)$ & \\
\hline 5 & $1.70 \mathrm{dd}$ (overlapped) & $1.22 \mathrm{dd}$ (overlapped) & $1.61 \mathrm{~m}$ \\
\hline $6 a$ & $1.66 \mathrm{~m}$ & $1.63 \mathrm{~m}$ & $1.60 \mathrm{~m}$ \\
\hline $6 b$ & $1.62 \mathrm{~m}$ & $1.58 \mathrm{~m}$ & $1.58 \mathrm{~m}$ \\
\hline $7 a$ & $1.76 \mathrm{~m}$ & $1.55 \mathrm{~m}$ & $1.76 \mathrm{~m}$ \\
\hline $7 \mathrm{~b}$ & $1.63 \mathrm{~m}$ & $1.35 \mathrm{~m}$ & $1.58 \mathrm{~m}$ \\
\hline 9 & $2.00 \mathrm{dd}(11.3,6.3)$ & $1.78 \mathrm{~m}$ & $2.05 \mathrm{dd}(10.7,6.6)$ \\
\hline $11 \mathrm{a}$ & 2.27 ddd $(17.3,11.3,3.5)$ & $2.06 \mathrm{~m}$ & $2.33 \mathrm{~m}$ \\
\hline $11 b$ & 2.14 ddd $(17.3,6.3,3.7)$ & $1.35 \mathrm{~m}$ & $2.19 \mathrm{~m}$ \\
\hline 12 & $5.37 \mathrm{dd}(3.7,3.5)$ & $5.30 \mathrm{dd}(3.8,3.3)$ & $5.37 \mathrm{dd}(3.8,3.1)$ \\
\hline $15 \alpha$ & 1.03 ddd $(14.1,4.2,2.5)$ & $0.99 \mathrm{~m}$ & $1.02 \mathrm{~m}$ \\
\hline $15 \beta$ & 1.83 ddd $(14.1,13.2,4.4)$ & $1.81 \mathrm{~m}$ & $1.63 \mathrm{~m}$ \\
\hline $16 \alpha$ & $2.60 \mathrm{ddd}(13.3,13.2,4.4)$ & $2.57 \mathrm{ddd}(13.4,13.4,4.0)$ & $1.75 \mathrm{~m}$ \\
\hline $16 \beta$ & 1.55 ddd $(13.3,4.2,2.5)$ & $1.55 \mathrm{~m}$ & $1.60 \mathrm{~m}$ \\
\hline 18 & $2.50 \mathrm{~s}$ & $2.51 \mathrm{~s}$ & $3.07 \mathrm{~d}(3.9)$ \\
\hline 19 & & & $3.26 \mathrm{~d}(3.9)$ \\
\hline 20 & $1.37 \mathrm{~m}$ & $1.34 \mathrm{~m}$ & \\
\hline $21 \mathrm{a}$ & $1.25 \mathrm{~m}$ & $1.22 \mathrm{~m}$ & $2.29 \mathrm{~m}$ \\
\hline $21 b$ & $1.20 \mathrm{~m}$ & $1.16 \mathrm{~m}$ & $1.62 \mathrm{~m}$ \\
\hline $22 \mathrm{a}$ & $1.75 \mathrm{~m}$ & $1.73 \mathrm{~m}$ & $1.61 \mathrm{~m}$ \\
\hline $22 b$ & $1.62 \mathrm{~m}$ & $1.62 \mathrm{~m}$ & $1.37 \mathrm{~m}$ \\
\hline $23 a$ & $3.71 \mathrm{~d}(12.0)$ & $1.21 \mathrm{~s}$ & $1.11 \mathrm{~s}$ \\
\hline $23 b$ & $3.69 \mathrm{~d}(12.0)$ & & \\
\hline $24 \mathrm{a}$ & $1.29 \mathrm{~s}$ & $4.11 \mathrm{~d}(11.4)$ & $1.18 \mathrm{~s}$ \\
\hline $24 b$ & & $3.50 \mathrm{~d}(11.4)$ & \\
\hline 25 & $1.30 \mathrm{~s}$ & $1.31 \mathrm{~s}$ & $1.22 \mathrm{~s}$ \\
\hline 26 & $0.90 \mathrm{~s}$ & $0.84 \mathrm{~s}$ & $0.84 \mathrm{~s}$ \\
\hline 27 & $1.36 \mathrm{~s}$ & $1.32 \mathrm{~s}$ & $1.30 \mathrm{~s}$ \\
\hline 29 & $1.23 \mathrm{~s}$ & $1.19 \mathrm{~s}$ & $0.97 \mathrm{~s}$ \\
\hline 30 & $0.95 \mathrm{~d}(7.1)$ & $0.93 \mathrm{~d}(6.3)$ & $0.94 \mathrm{~s}$ \\
\hline
\end{tabular}

${ }^{a}$ Assignments were made by a combination of 1D and 2D NMR experiment.
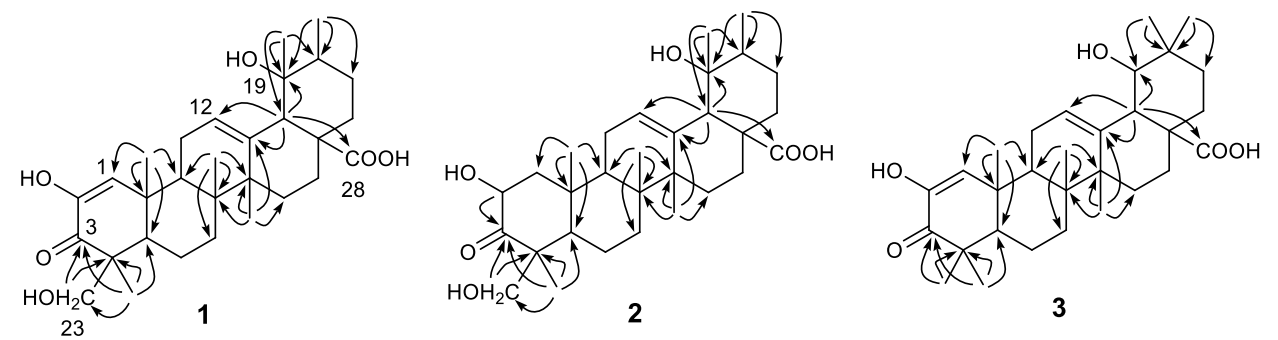

Figure 2. Observed key HMBC correlations of triterpenoids 1-3.

The HRESIMS data permitted the molecular formula of rubusacid $\mathrm{B}(2)$ to be assigned as $\mathrm{C}_{30} \mathrm{H}_{46} \mathrm{O}_{6}\left(m / z 525.3184[\mathrm{M}+\mathrm{Na}]^{+}\right.$, calcd. for $\mathrm{C}_{30} \mathrm{H}_{46} \mathrm{O}_{6} \mathrm{Na}$, 525.3187), which was consistent with its ${ }^{13} \mathrm{C}$ NMR data (Table 1 ). The close similarity of the ${ }^{1} \mathrm{H}$ (Table 2 ) and ${ }^{13} \mathrm{C}$ NMR spectroscopic data of $\mathbf{2}$ with those of $\mathbf{1}$, indicated that $\mathbf{2}$ is also an ursane-type triterpenoid. The difference of two mass units between $\mathbf{1}$ and $\mathbf{2}$, and the absence of the enol group $\left(\delta_{\mathrm{H}}\right.$ $\left.6.29, \mathrm{~s}(\mathrm{H}-1) ; \delta_{\mathrm{C}} 129.5(\mathrm{C}-1), 145.8(\mathrm{C}-2)\right)$ in ring A when compared with those of $\mathbf{1}$, suggested that the $\Delta^{1}$ double bond in $\mathbf{1}$ was hydrogenated in $\mathbf{2}$. This was confirmed by the HMBC correlation from $\mathrm{H}_{3}-25$ to $\mathrm{C}-1\left(\delta_{\mathrm{C}} 51.2\right)$ (Figure 2). The large coupling constant of $J_{1 \alpha, 2}=12.7 \mathrm{~Hz}$ suggested the axial position for $\mathrm{H}-2$. Moreover, the correlations of $\mathrm{H}-2 / \mathrm{H}_{3}-25, \mathrm{H}-2 / \mathrm{H}_{2}-24$, and $\mathrm{H}_{2}-24 / \mathrm{H}_{3}-25$ in the ROESY NMR experiment (Figure 3) confirmed the $\beta$-orientation for both $\mathrm{H}-2$ and the $\mathrm{CH}_{2} \mathrm{OH}$ group at C-4. In addition, the $\alpha$-orientation of $\mathrm{OH}-19$ was also determined by ROESY NMR experiment, in a similar way to $\mathbf{1}$ (Figure 3). Accordingly, 
the structure of 2 was deduced as $\left(2 R^{*}, 4 S^{*}, 5 R^{*}, 8 R^{*}, 9 R^{*}, 10 R^{*}, 14 S^{*}, 17 S^{*}, 18 S^{*}, 19 R^{*}, 20 R^{*}\right)$ $2 \alpha, 19 \alpha, 24$-trihydroxy-3-oxo-urs-12-en-28-oic acid.
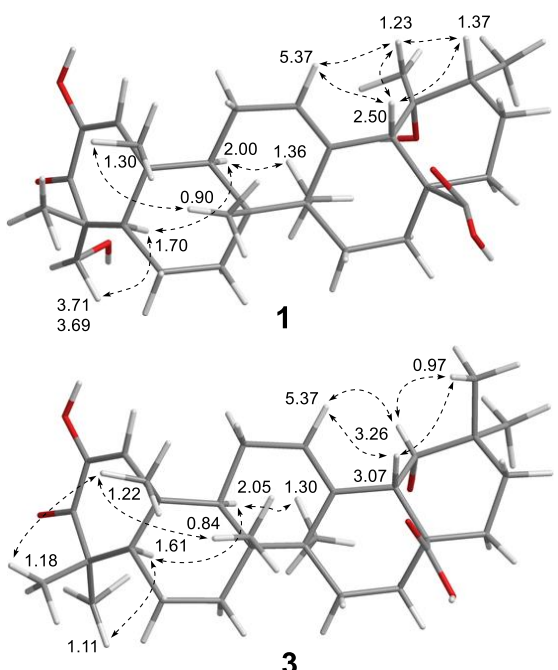
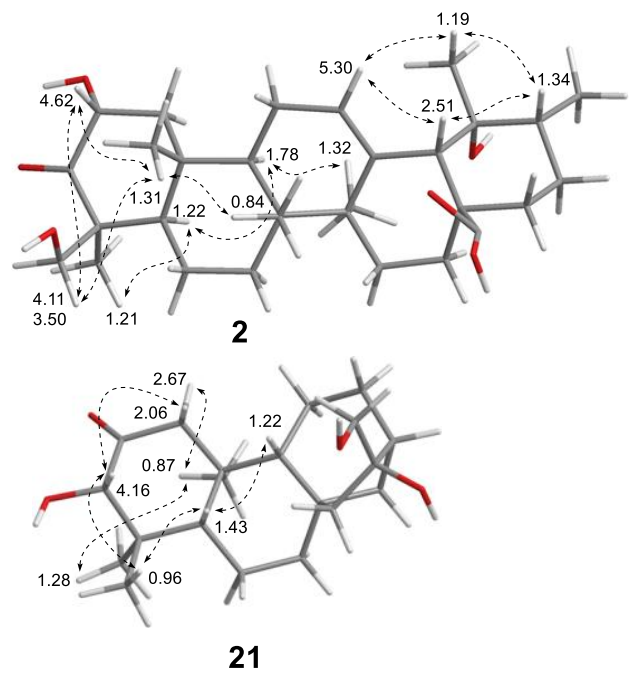

Figure 3. Observed key ROE correlations of compounds 1-3 and 21.

Rubusacid C (3) had a molecular formula of $\mathrm{C}_{30} \mathrm{H}_{44} \mathrm{O}_{5}$, as determined by HRESIMS $\left([\mathrm{M}+\mathrm{H}]^{+}\right.$ion at $m / z 485.3254$, calcd for $\left.\mathrm{C}_{30} \mathrm{H}_{45} \mathrm{O}_{5}, 485.3262\right)$ and ${ }^{13} \mathrm{C}$ NMR data (Table 1$)$. Like 1, the IR $\left(1695,1634 \mathrm{~cm}^{-1}\right)$ and UV $(266 \mathrm{~nm})$ absorption bands of 3 also indicated a cyclic enonic group. The ${ }^{1} \mathrm{H}$ (Table 2 ) and ${ }^{13} \mathrm{C}$ NMR data of 3 showed similarities to those of $\mathbf{1}$, with the obvious differences being the presence of a pair of germinal methyl groups at $\mathrm{C}-20\left(\delta_{\mathrm{H}} 0.97, \mathrm{~s} ; 0.94, \mathrm{~s}\right)$ and an oxygenated methine at $\mathrm{C}-19\left(\delta_{\mathrm{H}} 3.26, \mathrm{~d}, J=3.9 \mathrm{~Hz}\right.$; $\left.\delta_{\mathrm{C}} 82.4\right)$ in 3 , rather than the secondary methyl group and tertiary methyl group in $\mathbf{1}$. This implied that 3 is an oleanane-type triterpenoid, which agreed with the co-occurring terpenoid compounds 11-14 [20-23]. This was further supported by HMBC correlations (Figure 2) from $\mathrm{H}_{3}-29$ and $\mathrm{H}_{3}-30$ to $\mathrm{C}-19, \mathrm{C}-20$, and $\mathrm{C}-21$, and from $\mathrm{H}-18$ to $\mathrm{C}-19$. In addition, the $\mathrm{OH}-23$ in $\mathbf{1}$ was absent in $\mathbf{3}$, which was corroborated by the HMBC cross-peaks from $\mathrm{H}_{3}-24$ to $\mathrm{C}-23$. The relative configuration of 3 was determined by analyzing the coupling constants and ROESY data. The small $J$ value $(3.9 \mathrm{~Hz})$ between $\mathrm{H}-18$ and $\mathrm{H}-$ 19 was indicative of the equatorial orientation of H-19. Moreover, the ROE correlations from $\mathrm{H}-19$ to $\mathrm{H}-12, \mathrm{H}-18$, and $\mathrm{H}_{3}-29$ confirmed that $\mathrm{OH}-19$ was $\alpha$-oriented (Figure 3). The chirality of C-10 was assigned to be $R$, as evidenced from a positive CE at $274 \mathrm{~nm}$ and negative CEs at 215 and $333 \mathrm{~nm}$ in its ECD spectrum, which were comparable with (+)-cyrillins A and relevant analogues [34,37]. Therefore, the structure of $\mathbf{3}$ was defined as $(5 R, 8 R, 9 R, 10 R, 14 S, 17 R, 18 S, 19 S)-2,19 \alpha$-dihydroxy-olean-1,12-dien-28-oic acid.

Rubusone (21) was obtained as a white, amorphous powder. It had a molecular formula of $\mathrm{C}_{20} \mathrm{H}_{32} \mathrm{O}_{4}$ according to HRESIMS data analysis ([M+ $\left.\mathrm{H}\right]^{+} m / z 337.2389$, calcd for $\mathrm{C}_{20} \mathrm{H}_{33} \mathrm{O}_{4}, 337.2373$ ) and the ${ }^{13} \mathrm{C}$ NMR data (Table 1). The IR absorption bands at 3379 and $1701 \mathrm{~cm}^{-1}$ suggested the presence of hydroxyl and carbonyl groups, respectively. Inspection of the ${ }^{1} \mathrm{H}$ NMR spectroscopic data (in $\mathrm{C}_{6} \mathrm{D}_{6}$, Table 3 ) indicated the presence of three tertiary methyl groups $\left(\delta_{\mathrm{H}} 0.67(3 \mathrm{H}, \mathrm{s}, \mathrm{Me}-19), 0.69(3 \mathrm{H}, \mathrm{s}, \mathrm{Me}-20)\right.$, and $1.10(3 \mathrm{H}, \mathrm{s}, \mathrm{Me}-$ $18))$, an oxymethine resonance $\left(\delta_{\mathrm{H}} 3.62(1 \mathrm{H}, \mathrm{d}, J=3.8 \mathrm{~Hz}, \mathrm{H}-3)\right)$, and a hydroxymethylene group at $\delta_{\mathrm{H}} 3.37$ and $3.44\left(\mathrm{ABq}\right.$, each $\left.1 \mathrm{H}, \mathrm{d}, J=10.3 \mathrm{~Hz}, \mathrm{H}_{2}-17\right)$. A total of 20 carbon signals, including one ketone carbonyl at $\delta_{\mathrm{C}} 210.2$ (C-2) and three oxygenated at $\delta_{\mathrm{C}} 82.8(\mathrm{C}-3), 81.2$ (C-16), and 66.3 (C-17), were displayed in its ${ }^{13} \mathrm{C}$ NMR spectrum. The aforementioned NMR data were similar to those of the co-occurring compounds 22-25 [29-32], suggesting 4 is an ent-kaurane derivative. Detailed comparisons suggested that the 1D NMR data were closely related to those of $3 \alpha, 16 \beta, 17$-trihydroxy-ent-kaurane-2-one, which was previously isolated from Homalanthus acuminatus [38]. The only noticeable difference was that the chemical shifts of $\mathrm{CH}_{2} \mathrm{OH}-17\left(\delta_{\mathrm{H}}: 3.37\right.$ and $\left.3.44, \delta_{\mathrm{C}}: 66.3\right)$ in 21 were significantly distinguished 
when compared with $3 \alpha, 16 \beta, 17$-trihydroxy-ent-kaurane-2-one $\left(\delta_{\mathrm{H}}: 3.09\right.$ and $\left.3.12 ; \delta_{\mathrm{C}}: 69.8\right)$, indicating that these two compounds are epimeric at C-16. The $\alpha$-orientation of $\mathrm{OH}-16$, as with 22-25 [29-32], was confirmed by comparing the chemical shifts of C-16 and C-17 with reported data $[31,39]$. The magnitude of $J_{\mathrm{H}-5 / \mathrm{H}-6 \alpha}(11.6 \mathrm{~Hz})$ indicated that $\mathrm{H}-5$ was in axial position, and the ROE correlations of $\mathrm{H}-5$ with $\mathrm{H}-3 / \mathrm{H}-9$, and of $\mathrm{H}-3$ with $\mathrm{H}_{3}-18$ revealed their cofacial relationship (arbitrarily assigned as $\beta$-oriented). In turn, the ROE correlation of $\mathrm{H}_{3}-19$ and $\mathrm{H}_{3}-20$ was indicative of their $\alpha$-orientation. Additionally, the ECD spectrum of 21 showed a negative $C E$ at $280 \mathrm{~nm}$ arising from the $n \rightarrow \pi^{*}$ transition of the C-2 carbonyl group, indicative of an $S$ configuration for C-3 by using the octant rule [40,41]. Thus, the structure of $\mathbf{2 1}$ was elucidated as ( $3 S, 5 S, 8 S, 9 R, 10 S, 13 R, 16 R)-3 \alpha, 16 \alpha, 17$-trihydroxyent-kaur-2-one.

Table 3. ${ }^{1} \mathrm{H}(\delta$ in ppm, $600 \mathrm{MHz})$ and ${ }^{13} \mathrm{C}(\delta$ in ppm, $150 \mathrm{MHz})$ NMR data ${ }^{a}$ of 21.

\begin{tabular}{|c|c|c|c|c|c|}
\hline \multirow{2}{*}{ No. } & \multicolumn{2}{|c|}{21} & \multirow{2}{*}{ No. } & \multicolumn{2}{|c|}{21} \\
\hline & $\delta_{\mathrm{H}}(J \text { in } \mathrm{Hz})^{b}$ & $\delta_{\mathrm{H}}(J \text { in } \mathrm{Hz})^{c}$ & & $\delta_{\mathrm{H}}(J \text { in } \mathrm{Hz})^{b}$ & $\delta_{\mathrm{H}}(J \text { in } \mathrm{Hz})^{c}$ \\
\hline \multirow{2}{*}{1} & $1.37 \mathrm{~d}(12.4)$ & $2.06 \mathrm{~d}(12.2)$ & 12 & $1.62 \mathrm{~m} ; 1.65 \mathrm{~m}$ & $1.87 \mathrm{~m} ; 1.83 \mathrm{~m}$ \\
\hline & $2.41 \mathrm{~d}(12.4)$ & $2.67 \mathrm{~d}(12.2)$ & 13 & $1.88 \mathrm{~m}$ & $2.46 \mathrm{~m}$ \\
\hline 3 & $3.62 \mathrm{~d}(3.8)$ & $4.16 \mathrm{~s}$ & 14 & $1.57 \mathrm{~m} ; 0.69 \mathrm{~m}$ & $1.70 \mathrm{~m} ; 0.85 \mathrm{~m}$ \\
\hline 5 & 0.91 br d (11.6) & 1.43 br d (11.5) & 15 & $1.39 \mathrm{~m} ; 1.25 \mathrm{~m}$ & $1.63 \mathrm{~m} ; 1.35 \mathrm{~m}$ \\
\hline 6 & $1.32 \mathrm{~m} ; 1.05 \mathrm{~m}$ & $1.69 \mathrm{~m} ; 1.37 \mathrm{~m}$ & \multirow{2}{*}{17} & $3.44 \mathrm{~d}(10.3)$ & $4.12 \mathrm{~d}(11.0)$ \\
\hline 7 & $1.22 \mathrm{~m} ; 1.21 \mathrm{~m}$ & $1.56 \mathrm{~m} ; 1.53 \mathrm{~m}$ & & $3.37 \mathrm{~d}(10.3)$ & $4.05 \mathrm{~d}(11.0)$ \\
\hline 9 & 0.99 br d (6.7) & 1.22 br d (8.6) & 18 & $1.10 \mathrm{~s}$ & $0.96 \mathrm{~s}$ \\
\hline 11 & $1.62 \mathrm{~m} ; 1.18 \mathrm{~m}$ & $1.84 \mathrm{~m} ; 1.51 \mathrm{~m}$ & 19 & $0.67 \mathrm{~s}$ & $1.28 \mathrm{~s}$ \\
\hline $\mathrm{OH}-3$ & $3.72 \mathrm{~d}(3.8)$ & & 20 & $0.69 \mathrm{~s}$ & $0.87 \mathrm{~s}$ \\
\hline
\end{tabular}

$\overline{{ }^{a}}$ Assignments were made by a combination of $1 \mathrm{D}$ and $2 \mathrm{D}$ NMR experiments; ${ }^{b}$ Measured in $\mathrm{C}_{6} \mathrm{D}_{6} ;{ }^{c}$ Measured in $\mathrm{C}_{5} \mathrm{D}_{5} \mathrm{~N}$.

Nuclear factor- $\kappa \mathrm{B}(\mathrm{NF}-\kappa \mathrm{B})$ is an important transcription factor controlling different biological processes, such as immune differentiation and activation [42]. It has been regarded as a potential target for the regulation of dysfunction of immunity and inflammation. Recently, a few triterpenoids and diterpenoids from Stewartia sinensis [11] and Pseudotsuga sinensis [12] were found to have significant NF- $\kappa \mathrm{B}$ inhibitory effects. In the present study, all the isolated terpenoids (1-25) were evaluated for their NF- $\kappa$ B inhibitory activities. Among them, only three cucurbitane-type compounds, 15-17, showed potent inhibitory effects, with $\mathrm{IC}_{50}$ values of $0.08,0.61$, and $1.60 \mu \mathrm{M}$ (Table 4), respectively. The rest of the isolates were inactive (inhibition ration $<50 \%$ at $20 \mu \mathrm{M}$ ). Bortezomib (PS-341) was used as the positive control $\left(\mathrm{IC}_{50}: 0.44 \mu \mathrm{M}\right)$ [43]. Interestingly, some ent-labdane-type diterpenoid glycosides from Fructus Rubi have been reported to suppress the NF- $\kappa$ B signaling pathway [44], but the ent-kaurane-type diterpenoids isolated herein were inactive against NF- $\kappa$ B.

Table 4. Inhibitory activities of indicated compounds against NF- $\kappa$ B.

\begin{tabular}{cc}
\hline Compound & NF- $\boldsymbol{\kappa} \mathbf{B}\left(\mathbf{I C}_{\mathbf{5 0}}\right)^{a}$ \\
\hline $\mathbf{1 5}$ & $0.08 \pm 0.03 \mu \mathrm{M}$ \\
$\mathbf{1 6}$ & $0.61 \pm 0.12 \mu \mathrm{M}$ \\
$\mathbf{1 7}$ & $1.60 \pm 0.32 \mu \mathrm{M}$ \\
PS-341 $^{b}$ & $0.44 \pm 0.08 \mu \mathrm{M}$ \\
\hline
\end{tabular}

${ }^{a}$ These data are expressed as the mean SEM of triplicated experiments. ${ }^{b}$ Positive control.

In addition, the $70 \%$ ethanol extract of Fructus Rubi combined with fluconazole (FLC) has been previously found to have an anti-fungal activity against twenty-two FLCresistant Candida albicans strains [45]. Hence, all the isolated compounds were subjected to the same bioassay, but none of them were active. They were also evaluated for their anti-fungal effects against the C. albicans SC5314 sensitive strain, and only compound $\mathbf{1 2}$ showed a moderate inhibition ( $\mathrm{MIC}_{80}: 32 \mu \mathrm{g} / \mathrm{mL}$ ), whereas the other twenty-four isolates 
were inactive $\left(\mathrm{MIC}_{80}>64 \mu \mathrm{g} / \mathrm{mL}\right)$. Fluconazole $\left(\mathrm{MIC}_{80}: 0.125 \mu \mathrm{g} / \mathrm{mL}\right)$ was used as the positive control [46].

\section{Materials and Methods}

\subsection{General Experimental Procedures and Agents}

Optical rotations were obtained with a Rudolf Autopol IV at $21^{\circ} \mathrm{C}$. UV and IR spectra were recorded on a Hitachi U-2900E UV spectrophotometer (Hitachi High-Techologies Corporation, Tokyo, Japan) and a Thermo Scientific Nicolet Is5 FT-IR spectrometer (Thermo Fisher Scientific, San Jose, CA, USA), respectively. ECD spectra were collected on a JASCO810 spectropolarimeter (Jasco Analytical Instruments, Easton, PA, USA). ESIMS and HRESIMS were acquired on an Agilent 1100 LC/MSD mass spectrometer (Agilent, Santa Clara, CA, USA) and an AB Sciex Triple TOF 5600 spectrometer (AB Sciex Pte. Ltd, Singapore), respectively. 1D and 2D NMR spectra were recorded on Bruker Avance III 400 or $600 \mathrm{MHz}$ spectrometers (Bruker, Fallanden, Switzerland), using the residual solvent signals as the internal standard. All chemical shifts were expressed in ppm. Semi-preparative HPLC was performed on a Waters e2695 system coupled with a 2998 photodiode array (PDA) detector and a 2424 evaporative light-scattering detector (ELSD) (Waters, Milford, MA, USA). A Cosmosil C18 column $(5 \mu \mathrm{M}, 10 \times 250 \mathrm{~mm}$; flow rate: $3.0 \mathrm{~mL} / \mathrm{min})$ and an $\mathrm{X}$ bridge C18 column $(5 \mu \mathrm{M}, 10 \times 250 \mathrm{~mm}$; flow rate: $3.0 \mathrm{~mL} / \mathrm{min})$ were utilized. Thin-layer chromatography (TLC) was performed on pre-coated plates $\left(\mathrm{GF}_{254}, 0.25 \mathrm{~mm}\right.$, Kang-Bi-Nuo Silysia Chemical Ltd., Yantai, China). TLC spots were visualized under UV light (254 or $365 \mathrm{~nm}$ ) and by spraying with $5 \% \mathrm{H}_{2} \mathrm{SO}_{4}$ / vanillin, followed by heating to $120^{\circ} \mathrm{C}$. Candida albicans strains (the resistant strain 901, and the sensitive strain 5314) were provided by Dr William A. Fonzi from the Department of Microbiology and Immunology, Georgetown University, Washington DC, USA. RPMI-1640 medium was purchased from Gibco (Life Technologies, Carlsbad, CA, USA). Fluconazole (FLC) was purchased from Pfizer-Roerig Pharmaceuticals (New York, NY, USA).

\subsection{Plant Material}

The unripe fruits of $R$. chingii were purchased from Shanghai Chinese Traditional Medicine Drinking Tablet Co., Ltd., Shanghai, China. They were taxonomically identified by one of the authors (Mr. B. Han). A voucher specimen (No. 20190319) was deposited at the herbarium of the School of Pharmacy at Fudan University.

\subsection{Extraction and Isolation}

The air-dried and powdered unripe fruits $(28.0 \mathrm{~kg}$ ) were extracted with $70 \%$ ethanol $(5 \times 20 \mathrm{~L}$, each time for $24 \mathrm{~h})$ at room temperature. After filtration, the solvent was removed under vacuum to give a dark green residue $\left(5.7 \mathrm{~kg}\right.$, semi-dry), which was suspended in $\mathrm{H}_{2} \mathrm{O}$ $(6 \mathrm{~L})$ and then extracted successively with petroleum ether $(\mathrm{PE}, 3 \times 6 \mathrm{~L})$, EtOAc $(3 \times 6 \mathrm{~L})$, and $n$-BuOH $(3 \times 6 \mathrm{~L})$. The EtOAc-soluble extract $(325.3 \mathrm{~g})$ was subjected to a silica gel column with a stepwise gradient-elution of PE-EtOAc $(30: 1 \rightarrow 20: 1 \rightarrow 10: 1 \rightarrow 5: 1 \rightarrow 1: 1 \rightarrow$ 1:5 $\rightarrow$ neat EtOAc), to afford nine fractions (Fr.1-9), according to TLC analysis. Fr.3 (10.4 g) was chromatographed over a silica gel column $\left(\mathrm{CH}_{2} \mathrm{Cl}_{2}-\mathrm{MeOH}, 10: 1 \rightarrow 5: 1 \rightarrow 1: 1\right)$ to give six subfractions, Fr.3A-F. Compound $4(3.0 \mathrm{mg})$ was obtained from Fr.3C (104 mg) by Sephadex LH-20 (MeOH), followed by HPLC purification $\left(\mathrm{MeOH}-\mathrm{H}_{2} \mathrm{O}, 70: 30, t_{\mathrm{R}}=17.5 \mathrm{~min}\right)$. Fr. 4 $(6.4 \mathrm{~g})$ was fractionated on an MCI column with a step gradient elution of $\mathrm{MeOH}-\mathrm{H}_{2} \mathrm{O}$ $(50: 50 \rightarrow 70: 30 \rightarrow 85: 15 \rightarrow 100: 0)$, and six fractions (Fr.4A-F) were collected. Separation of Fr.4E (700 mg) over Sephadex LH-20 (MeOH) and semi-preparative HPLC (MeOH-H ${ }_{2} \mathrm{O}$, 88:12) afforded compound $7\left(28 \mathrm{mg}, t_{\mathrm{R}}=15.7 \mathrm{~min}\right)$. Fr.5 (23.0 g) was chromatographed over a silica gel column $\left(\mathrm{CH}_{2} \mathrm{Cl}_{2}-\mathrm{MeOH}, 20: 1 \rightarrow 10: 1 \rightarrow 5: 1 \rightarrow 1: 1\right)$ to give eight fractions, Fr.5A-H. Compounds $1\left(1.0 \mathrm{mg}, t_{\mathrm{R}}=12.9 \mathrm{~min}\right)$ and $3\left(1.0 \mathrm{mg}, t_{\mathrm{R}}=18.5 \mathrm{~min}\right)$ were obtained from Fr.5A $(1.2 \mathrm{~g})$ by Sephadex LH-20 (MeOH), followed by semi-preparative HPLC (MeOH-H $\left.\mathrm{H}_{2} \mathrm{O}, 70: 30\right)$. Purification of Fr.5B (400 mg) by semi-preparative HPLC (MeCN$\left.\mathrm{H}_{2} \mathrm{O}, 45: 55\right)$ yielded compounds $16\left(0.8 \mathrm{mg}, t_{\mathrm{R}}=18.7 \mathrm{~min}\right)$ and $17\left(2.5 \mathrm{mg}, t_{\mathrm{R}}=17.3 \mathrm{~min}\right)$. 
Fr.5C (600 mg) was further purified by Sephadex LH-20 (MeOH) to give subfractions Fr.5C$1-4$. Compounds $18\left(1.5 \mathrm{mg}, t_{\mathrm{R}}=16.0 \mathrm{~min}\right)$ and $19\left(2.0 \mathrm{mg}, t_{\mathrm{R}}=17.4 \mathrm{~min}\right)$ were isolated from Fr.5C-1 (130 mg) by semi-preparative $\mathrm{MeCN}-\mathrm{H}_{2} \mathrm{O}, 43: 57$. By employing the same HPLC $\left(\mathrm{MeOH}-\mathrm{H}_{2} \mathrm{O}, 67: 33\right)$ system, Compound $15\left(6.0 \mathrm{mg}, t_{\mathrm{R}}=14.2 \mathrm{~min}\right)$ was purified from Fr.5C-2 (264 mg), whereas compound $20\left(2.2 \mathrm{mg}, t_{\mathrm{R}}=23.5 \mathrm{~min}\right)$ was obtained from Fr.5C-3 $(80 \mathrm{mg})$. Fr.5D (1.2 g) was fractionated by Sephadex LH-20 (MeOH) followed by semipreparative HPLC (MeCN-H $\left.\mathrm{H}_{2} \mathrm{O}, 50: 50\right)$ to furnish compounds 2 ( $\left.2.0 \mathrm{mg}, t_{\mathrm{R}}=16.5 \mathrm{~min}\right), 8$ $\left(5.0 \mathrm{mg}, t_{\mathrm{R}}=12.3 \mathrm{~min}\right)$, and $14\left(6.0 \mathrm{mg}, t_{\mathrm{R}}=11.2 \mathrm{~min}\right)$. Fr.6 $(6.7 \mathrm{~g})$ was fractionated on an $\mathrm{MCI}$ column with a step gradient elution of $\mathrm{MeOH}-\mathrm{H}_{2} \mathrm{O}(30: 70 \rightarrow 50: 50 \rightarrow 70: 30 \rightarrow 85: 15 \rightarrow$ 100:0), and eight fractions (Fr.6A-H) were collected. Fr.6B (840 mg) was further fractionated by Sephadex LH-20 (MeOH) to give the subfractions Fr.6B-1-3. Fr.6B-2 (260 mg) was purified by semi-preparative HPLC ( $\left.\mathrm{MeOH}-\mathrm{H}_{2} \mathrm{O}, 80: 20\right)$ to afford compounds 9 ( $2.0 \mathrm{mg}$, $\left.t_{\mathrm{R}}=14.5 \mathrm{~min}\right)$ and $10\left(3.3 \mathrm{mg}, t_{\mathrm{R}}=16.7 \mathrm{~min}\right)$. Fr.6F $(0.9 \mathrm{~g})$ was separated over silica gel $\left(\mathrm{CH}_{2} \mathrm{Cl}_{2}-\mathrm{MeOH}, 20: 1 \rightarrow 10: 1 \rightarrow 5: 1 \rightarrow 1: 1\right)$ to give four subfractions (Fr.6F-1-4). Compound $5\left(25.1 \mathrm{mg}, t_{\mathrm{R}}=11.3 \mathrm{~min}\right)$ was purified from Fr.6F-1 by Sephadex LH-20 (MeOH), followed by semi-preparative HPLC purification $\left(\mathrm{MeOH}-\mathrm{H}_{2} \mathrm{O}, 77: 23\right)$. Fr.6F-3 was purified by semi-preparative HPLC ( $\left.\mathrm{MeOH}-\mathrm{H}_{2} \mathrm{O}, 74: 26\right)$ to afford compounds $6\left(2.2 \mathrm{mg}, t_{\mathrm{R}}=21.7 \mathrm{~min}\right)$ and $12\left(44.3 \mathrm{mg}, t_{\mathrm{R}}=20.6 \mathrm{~min}\right)$. Fr.6E $(0.9 \mathrm{~g})$ was rechromatographed by silica gel with $\mathrm{CH}_{2} \mathrm{Cl}_{2}-\mathrm{MeOH}$ (9:1), and six fractions (Fr.6E-1-6) were obtained. Compound 13 (7.0 mg, $\left.t_{\mathrm{R}}=16.3 \mathrm{~min}\right)$ was isolated from Fr.6E-4 $(170 \mathrm{mg})$ by semi-preparative HPLC $\left(\mathrm{MeOH}-\mathrm{H}_{2} \mathrm{O}\right.$, 71:29). Fr.7 (4.9 g) was fractionated on an MCI column with a step gradient elution of $\mathrm{MeOH}-\mathrm{H}_{2} \mathrm{O}(30: 70 \rightarrow 50: 50 \rightarrow 70: 30 \rightarrow 85: 15 \rightarrow 100: 0)$ and seven fractions (Fr.7A-G) were obtained. Separation of Fr.7C (200 mg) over Sephadex LH-20 (MeOH) and semi-preparative HPLC $\left(\mathrm{MeCN}-\mathrm{H}_{2} \mathrm{O}, 30: 70\right)$ afforded compounds $21\left(0.7 \mathrm{mg}, t_{\mathrm{R}}=13.7 \mathrm{~min}\right)$ and $22(49.1 \mathrm{mg}$, $\left.t_{\mathrm{R}}=17.1 \mathrm{~min}\right)$. Fr.7D $(550 \mathrm{mg})$ was purified by semi-preparative HPLC $\left(\mathrm{MeOH}-\mathrm{H}_{2} \mathrm{O}, 73: 27\right)$ to furnish compounds $23\left(18.5 \mathrm{mg}, t_{\mathrm{R}}=9.2 \mathrm{~min}\right)$ and $24\left(18.7 \mathrm{mg}, t_{\mathrm{R}}=11.7 \mathrm{~min}\right)$. Fr.8 $(16 \mathrm{~g})$ was fractionated on an MCI column with a step gradient elution of $\mathrm{MeOH}-\mathrm{H}_{2} \mathrm{O}(30: 70 \rightarrow$ 50:50 $\rightarrow$ 70:30 $\rightarrow$ 85:15 $\rightarrow$ 100:0) and six fractions (Fr.8A-F) were obtained. Fr.8B (1.09 g) was further separated on a Sephadex LH-20 (MeOH) to give subfractions Fr.8B-1-6. Fr.8B-5 $(0.7 \mathrm{~g})$ was purified by semi-preparative $\mathrm{HPLC}\left(\mathrm{MeOH}-\mathrm{H}_{2} \mathrm{O}, 55: 45\right)$ to afford compound $25\left(5.0 \mathrm{mg}, t_{\mathrm{R}}=11.2 \mathrm{~min}\right)$. Purification of subfraction Fr.8B-6 (0.8 g) by semi-preparative HPLC (MeCN-H $\left.{ }_{2} \mathrm{O}, 35: 65\right)$ yielded compound $11\left(3.0 \mathrm{mg}, t_{\mathrm{R}}=22.4 \mathrm{~min}\right)$.

$(4 R, 5 R, 8 R, 9 R, 10 R, 14 S, 17 S, 18 S, 19 R, 20 R)-2,19 \alpha, 23-T r i h y d r o x y-3-o x o-u r s-1,12-d i e n-28-o i c$ acid (rubusacid A, 1). White powder; $[\alpha]_{\mathrm{D}}^{21} 14.0(c 0.2, \mathrm{MeOH}) ; \mathrm{UV}(\mathrm{MeOH}) \lambda_{\max }(\log \varepsilon)$ $265(2.31) \mathrm{nm} ; \operatorname{ECD}\left(c 2.67 \times 10^{-3} \mathrm{M}, \mathrm{MeOH}\right) \lambda_{\max }(\Delta \varepsilon): 217(-16.3), 274(+13.9), 330(-3.0)$ nm; IR (KBr) $v_{\max } 3576,3446,2970,2937,2870,1721,1703,1690,1644,1464,1402,1379,1270$, 1242, 1157, 1058, 931, 863, $754 \mathrm{~cm}^{-1} ;{ }^{1} \mathrm{H}$ and ${ }^{13} \mathrm{C}$ NMR data, see Tables 1 and 2; ESIMS $m / z 499[\mathrm{M}-\mathrm{H}]^{-}$; HRESIMS $m / z 499.3067[\mathrm{M}-\mathrm{H}]^{-}$(calcd for $\mathrm{C}_{30} \mathrm{H}_{43} \mathrm{O}_{6}, 499.3065$, $\Delta=0.3 \mathrm{ppm})$.

$\left(2 R^{*}, 4 S^{*}, 5 R^{*}, 8 R^{*}, 9 R^{*}, 10 R^{*}, 14 S^{*}, 17 S^{*}, 18 S^{*}, 19 R^{*}, 20 R^{*}\right)-2 \alpha, 19 \alpha, 24$-Trihydroxy-3-oxo-urs12-en-28-oic acid (rubusacid B, 2). White powder; [ $\alpha]_{\mathrm{D}}^{21} 11.7$ (c 0.1, MeOH); UV (MeOH) $\lambda_{\max }(\log \varepsilon) 202(2.14) \mathrm{nm} ; \mathrm{ECD}\left(c 1.33 \times 10^{-3} \mathrm{M}, \mathrm{MeOH}\right) \lambda_{\max }(\Delta \varepsilon): 217(-5.3) \mathrm{nm} ; \mathrm{IR}$ $(\mathrm{KBr}) v_{\max } 3446,2975,2927,2848,1703,1691,1459,1387,1210,1185,1140,1053,1028,975$, $868 \mathrm{~cm}^{-1} ;{ }^{1} \mathrm{H}$ and ${ }^{13} \mathrm{C}$ NMR data, see Tables 1 and 2; ESIMS $m / z 501[\mathrm{M}-\mathrm{H}]^{-}, 525[\mathrm{M}+$ $\mathrm{Na}]^{+}$; HRESIMS $m / z 525.3184[\mathrm{M}+\mathrm{Na}]^{+}$(calcd for $\mathrm{C}_{30} \mathrm{H}_{46} \mathrm{O}_{6} \mathrm{Na}, 525.3187, \Delta=-0.4 \mathrm{ppm}$ ).

$(5 R, 8 R, 9 R, 10 R, 14 S, 17 R, 18 S, 19 S)-2,19 \alpha$-Dihydroxy-olean-1,12-dien-28-oic acid (rubusacid C, 3). White powder; $[\alpha]_{\mathrm{D}}^{21} 16.3(c 0.1, \mathrm{MeOH}) ; \mathrm{UV}(\mathrm{MeOH}) \lambda_{\max }(\log \varepsilon) 266(1.53) \mathrm{nm}$; $\operatorname{ECD}\left(c 2.75 \times 10^{-3} \mathrm{M}, \mathrm{MeOH}\right) \lambda_{\max }(\Delta \varepsilon): 215(-20.5), 274(+12.8), 333(-4.0) \mathrm{nm} ; \mathrm{IR}$ $(\mathrm{KBr}) v_{\max } 3571,3446,2972,2935,2868,1706,1695,1634,1462,1407,1384,1237,1212,1157$, 1050, 936, 756, $649 \mathrm{~cm}^{-1} ;{ }^{1} \mathrm{H}$ and ${ }^{13} \mathrm{C}$ NMR data, see Tables 1 and 2; ESIMS $\mathrm{m} / z 485$ [M + $\mathrm{H}]^{+}$and $507[\mathrm{M}+\mathrm{Na}]^{+} ; \mathrm{HRESIMS} m / z 485.3254[\mathrm{M}+\mathrm{H}]^{+}$(calcd for $\mathrm{C}_{30} \mathrm{H}_{45} \mathrm{O}_{5}, 485.3262$, $\Delta=-1.6 \mathrm{ppm})$.

$(3 S, 5 S, 8 S, 9 R, 10 S, 13 R, 16 R)-3 \alpha, 16 \alpha, 17-T r i h y d r o x y-e n t-k a u r-2-o n e$ (rubusone, 21). White powder; $[\alpha]_{\mathrm{D}}^{21}-30.2(c \quad 0.04, \mathrm{MeOH}) ; \mathrm{UV}(\mathrm{MeOH}) \lambda_{\max }(\log \varepsilon) 202$ (1.53) nm; ECD 
$\left(c 1.18 \times 10^{-3} \mathrm{M}, \mathrm{MeOH}\right) \lambda_{\max }(\Delta \varepsilon): 285(-8.7) \mathrm{nm}$; IR $(\mathrm{KBr}) v_{\max } 3379,2935,2865,1701$, $1619,1514,1449,1379,1317,1290,1207,1182,1142,1043,916,871 \mathrm{~cm}^{-1} ;{ }^{1} \mathrm{H}$ and ${ }^{13} \mathrm{C}$ NMR data, see Tables 1 and 3; ESIMS $m / z 337[\mathrm{M}+\mathrm{H}]^{+}, 359[\mathrm{M}+\mathrm{Na}]^{+}$; HRESIMS $m / z$ 337.2389 $[\mathrm{M}+\mathrm{H}]^{+}$(calcd for $\mathrm{C}_{20} \mathrm{H}_{33} \mathrm{O}_{4}, 337.2373, \Delta=4.6 \mathrm{ppm}$ ).

\subsection{NF- $\kappa B$ Inhibitory Assay}

HEK293 with a stable NF- $\kappa$ B expression cell line was used for the luciferase assay $[11,12,47]$. Cells were maintained at $37^{\circ} \mathrm{C}$ and $5 \% \mathrm{CO}_{2}$ atmosphere in Dulbecco's modified Eagle's medium with $100 \mathrm{U} / \mathrm{mL}$ benzylpenicillin $100 \mu \mathrm{g} / \mathrm{mL}$ streptomycin, $2 \mathrm{mM}$ glutamine, and $10 \%$ fetal bovine serum. Before seeding in 96-well plates, the cells were stained for $1 \mathrm{~h}$ in serum-free medium supplemented with $2 \mu$ cell Tracker Green CMFDA. Cells were seeded into 96-well plates and incubated for $24 \mathrm{~h}$, and then treated with different concentrations of the tested compounds followed by stimulation with $20 \mathrm{ng} / \mathrm{mL}$ TNF- $\alpha$. The luciferase substrate was added to each well after incubation for $6 h$, and then the released luciferin signal was detected using an EnVision microplate reader. The $\mathrm{IC}_{50}$ value was derived from a nonlinear regression model (curve-fit), based on a sigmoidal dose response curve (variable slope) and computed using Graphpad Prism 5 (Graphpad Software). Bortezomib (PS-341, CAS No. 179324-69-7) was used as the positive control $[11,12,43]$.

\subsection{Anti-Fungal Susceptibility Assay}

An anti-fungal assay was carried out on the basis of the Clinical and Laboratory Standards Institute (CLSI) method M27-A3 [45,48]. A single colony of Candida albicans (the resistant strain 901 or the sensitive strain 5314) was chosen from Sabouraud's agar and then inoculated in yeast extract peptone dextrose medium (YEPD) for activation by shake bottled cultivation $\left(200 \mathrm{rpm}, 37^{\circ} \mathrm{C}\right)$. After $16 \mathrm{~h}$, fungi in the late-exponential growth phase were obtained, followed by being adjusted to $1 \times 10^{3}-5 \times 10^{3} \mathrm{CFU} / \mathrm{mL}$ with RPMI 1640 medium. The density of the fungi in 96-well plates was $10^{3} \mathrm{CFU} / \mathrm{mL}$, while the final concentrations of the test compounds ranged from 64 to $0.125 \mu \mathrm{g} / \mathrm{mL}$ in triplicate. The assay volume in each well was $100 \mu \mathrm{L}$ with $\mathrm{MIC}_{80}$ determined following $48 \mathrm{~h}$ incubation at $37^{\circ} \mathrm{C}$. Optical density was measured with a microplate reader (Multiskan MK3; Labsystems, Nantaa, Finland) at $630 \mathrm{~nm}$. $\mathrm{MIC}_{80}$ was determined as the lowest concentration of the drugs that inhibited growth by $80 \%$ compared with the positive control. Fluconazole was used as the positive control $[45,46]$.

\section{Conclusions}

Previous phytochemical studies on the fruits and leaves of $R$. chingii were extensively reviewed [2,5]. Around 15 triterpenoids and 17 diterpenoids have so far been obtained from $R$. chingii $[2,5,49]$. In the present work, we focused on triterpenoids and diterpenoids from the unripe fruits of $R$. chingii. Three highly oxygenated triterpenoids (rubusacids A-C, 1-3) and one ent-kaurane-type diterpenoid (rubusone, 21) were reported that were hitherto unknown. Compounds $\mathbf{1}$ and $\mathbf{3}$ possess a special diosphenol unit in ring A. Diosphenols are $\alpha$-diketones, in which one of the carbonyls is enolized; they are part of the structure of several products of natural and synthetic origin, but are quite rare in naturally occurring ursane- and oleanane-type pentacyclic triterpenoids. To our knowledge, only a few plantoriginated oleanane-/ursane-type [13,50-53] and one biotransformed ursane-type [54] triterpenoids have such a moiety in ring A. These cucurbitane-type tetracyclic triterpenoids (15-20) were obtained from the unripe fruits of $R$. chingii for the first time. Regarding the bioactivity evaluations, three isolates (15-17) showed potent inhibitory effects against NF- $\kappa$ B. It is worth noting that some cucurbitane-type tetracyclic triterpenoid glycosides from Momordica charantia [55] have also been found to have this kind of effect. The major component, $2 \alpha, 3 \alpha, 23$-trihydroxy-urs-12-en-28-oic acid (12), might be the principle in the anti-fungal activity of $70 \%$ ethanol Fructus Rubi [45]. In general, the above findings expanded the terpenoic structure diversity of $R$. chingii and could provide useful clues for 
the discovery and development of new therapeutic or preventive agents for the treatment of NF- $\kappa$ B related diseases.

Supplementary Materials: The following are available online, ${ }^{1} \mathrm{H} N M R,{ }^{13} \mathrm{C} N M R,{ }^{1} \mathrm{H}-{ }^{1} \mathrm{H} C O S Y$, HMBC, ROESY, and HRESIMS spectra of compounds 1-3 and $\mathbf{2 1}$ are available as supporting information.

Author Contributions: J.W., J.X. and C.-X.J. performed the isolation, purification, and structure determination. X.-J.W., N.G., X.-Y.W., Y.Z. and B.H. worked in bioassays and biological data analyses. J.L. and J.-F.H. designed the whole experiments and revised the paper. All authors have read and agreed to the published version of the manuscript.

Funding: This work was supported by NSFC grants (Nos. 21937002, 81773599, 21772025), the National Mega-Project for Innovative Drugs from MOST (No. 2019ZX09735-002), the Youth Project Fund of Minhang Hospital Affiliated to Fudan University (2018MHJC07), Shanghai Natural Science Fund (17ZR1425100), and a special fund for the talent development in Minhang District.

Data Availability Statement: All data and figures generated or used during the study appear in the submitted article.

Acknowledgments: All authors are grateful to William A. Fonzi (the Department of Microbiology and Immunology, Georgetown University, Washington, DC, USA) for providing the Candida albicans strains.

Conflicts of Interest: The authors declare no conflict of interest.

Sample Availability: Samples of the compounds 1-25 are available from the authors.

\section{References}

1. Lu, L.-D.; Boufford, D.E. Flora of China; Wu, Z.-Y., Raven, P.H., Eds.; Science Press \& Missouri Botanical Garden Press: Beijing, China; St. Louis, MO, USA, 2003; Volume 9, pp. 195-285.

2. Sheng, J.-Y.; Wang, S.-Q.; Liu, K.-H.; Zhu, B.; Zhang, Q.-Y.; Qin, L.-P.; Wu, J.-J. Rubus chingii Hu: An overview of botany, traditional uses, phytochemistry, and pharmacology. Chin. J. Nat. Med. 2020, 18, 401-416. [CrossRef]

3. Ohtani, K.; Yang, C.-R.; Miyajima, C.; Zhou, J.; Tanaka, O. Labdane-type diterpene glycosides from fruits of Rubus foliolosus. Chem. Pharm. Bull. 1991, 39, 2443-2445. [CrossRef]

4. Chinese Pharmacopoeia Commission. Pharmacopoeia of the People's Republic of China part I; Chinese Medical Science and Technology Press: Beijing, China, 2020; pp. 399-400.

5. Yu, G.-H.; Luo, Z.-Q.; Wang, W.-B.; Li, Y.-H.; Zhou, Y.-T.; Shi, Y.-Y. Rubus chingii Hu: A review of the phytochemistry and pharmacology. Front. Pharmacol. 2019, 10, 799. [CrossRef]

6. Zeng, H.-J.; Liu, Z.; Wang, Y.-P.; Yang, D.; Yang, R.; Qu, L.-B. Studies on the anti-aging activity of a glycoprotein isolated from Fupenzi (Rubus chingii Hu.) and its regulation on klotho gene expression in mice kidney. Int. J. Biol. Macromol. 2018, 119, 470-476. [CrossRef] [PubMed]

7. Zhang, T.-T.; Yang, L.; Jiang, J.-G. Bioactive comparison of main components from unripe fruits of Rubus chingii Hu and identification of the effective component. Food Funct. 2015, 6, 2205-2214. [CrossRef]

8. Chen, Y.; Wang, Y.-J.; Xu, L.-L.; Jia, Y.-N.; Xue, Z.-H.; Zhang, M.; Phisalaphong, M.; Chen, H.-X. Ultrasound-assisted modified pectin from unripe fruit pomace of raspberry (Rubus chingii $\mathrm{Hu}$ ): Structural characterization and anti-oxidant activities. LWT-Food Sci. Technol. 2020, 134, 110007. [CrossRef]

9. Chen, Y.; Chen, Z.-Q.; Guo, Q.-W.; Gao, X.-D.; Ma, Q.-Q.; Xue, Z.-H.; Ferri, N.; Zhang, M.; Chen, H.-X. Identification of ellagitannins in the unripe fruit of Rubus chingii $\mathrm{Hu}$ and evaluation of its potential anti-diabetic activity. J. Agric. Food Chem. 2019, 67, 7025-7039. [CrossRef]

10. Li, H.; Liang, Y.-R.; Chen, S.-X.; Wang, W.-X.; Zou, Y.-K.; Nuryyeva, S.; Houk, K.N.; Xiong, J.; Hu, J.-F. Amentotaxins C-V, structurally diverse diterpenoids from the leaves and twigs of the vulnerable conifer Amentotaxus argotaenia and their cytotoxic effects. J. Nat. Prod. 2020, 83, 2129-2144. [CrossRef] [PubMed]

11. Wan, J.; Zang, Y.; Xiao, D.-A.; Li, N.; Li, J.-M.; Jin, Z.-X.; Chen, D.-L.; Xiong, J.; Li, J.; Hu, J.-F. Stewartiacids A-N, C-23 carboxylated triterpenoids from Chinese stewartia and their inhibitory effects against ATP-citrate lyase and NF- $\kappa$ B. RSC Adv. 2020, 10, 3343-3356. [CrossRef]

12. Huang, T.; Ying, S.-H.; Li, J.-Y.; Chen, H.-W.; Zhang, Y.; Wang, W.-X.; Li, J.; Xiong, J.; Hu, J.-F. Phytochemical and biological studies on rare and endangered plants endemic to China. Part XV. Structurally diverse diterpenoids and sesquiterpenoids from the vulnerable conifer Pseudotsuga sinensis. Phytochemistry 2020, 169, 112184. [CrossRef]

13. Hattori, M.; Kuo, K.-P.; Shu, Y.-Z.; Tezuka, Y.; Kikuchi, T.; Namba, T. A triterpene from the fruits of Rubus chingii. Phytochemistry 1988, 27, 3975-3976. [CrossRef]

14. Wiemann, J.; Deckelmann, A.M.; Csuk, R. A remarkably simple and convergent partial synthesis of pomolic acid. Tetrahedron Lett. 2016, 57, 3952-3953. [CrossRef] 
15. Sashida, Y.; Ogawa, K.; Mori, N.; Yamanouchi, T. Triterpenoids from the fruit galls of Actinidia polygama. Phytochemistry 1992, 31, 2801-2804. [CrossRef]

16. Xu, H.-X.; Zeng, F.-Q.; Wan, M.; Sim, K.-Y. Anti-HIV triterpene acids from Geum japonicum. J. Nat. Prod. 1996, 59, 643-645. [CrossRef]

17. Zhou, X.-H.; Kasai, R.; Ohtani, K.; Tanaka, O.; Nie, R.-L.; Yang, C.-R.; Zhou, J.; Yamasaki, K. Oleanane and ursane glucosides from Rubus species. Phytochemistry 1992, 31, 3642-3644.

18. Kashiwada, Y.; Wang, H.-K.; Nagao, T.; Kitanaka, S.; Yasuda, I.; Fujioka, T.; Yamagishi, T.; Cosentino, L.M.; Kozuka, M.; Okabe, H.; et al. Anti-AIDS agents. 30. Anti-HIV activity of oleanolic acid, pomolic acid, and structurally related triterpenoids. J. Nat. Prod. 1998, 61, 1090-1095. [CrossRef]

19. D'Abrosca, B.; Fiorentino, A.; Monaco, P.; Pacifico, S. Radical-scavenging activities of new hydroxylated ursane triterpenes from cv. Annurca apples. Chem. Biodivers. 2005, 2, 953-958. [CrossRef] [PubMed]

20. Zeng, N.; Shen, Y.; Li, L.-Z.; Jiao, W.-H.; Gao, P.-Y.; Song, S.-J.; Chen, W.-S.; Lin, H.-W. Anti-inflammatory triterpenes from the leaves of Rosa laevigata. J. Nat. Prod. 2011, 74, 732-738. [CrossRef]

21. Ullah, F.; Hussain, H.; Hussain, J.; Bukhari, I.A.; Khan, M.T.H.; Choudhary, M.I.; Gilani, A.H.; Ahmad, V.U. Tyrosinase inhibitory pentacyclic triterpenes and analgesic and spasmolytic activities of methanol extracts of Rhododendron collettianum. Phytother. Res. 2007, 21, 1076-1081. [CrossRef]

22. Joo, H.; Lee, H.-J.; Shin, E.-A.; Kim, H.; Seo, K.-H.; Baek, N.-I.; Kim, B.; Kim, S.-H. c-Jun N-terminal kinase-dependent endoplasmic reticulum stress pathway is critically involved in arjunic acid induced apoptosis in non-small cell lung cancer cells. Phytother. Res. 2016, 30, 596-603. [CrossRef]

23. Yeo, H.; Park, S.-Y.; Kim, J. A-ring contracted triterpenoid from Rosa multiflora. Phytochemistry 1998, 48, 1399-1401. [CrossRef]

24. Wu, P.-L.; Lin, F.-W.; Wu, T.-S.; Kuoh, C.-S.; Lee, K.-H.; Lee, S.-J. Cytotoxic and anti-HIV principles from the rhizomes of Begonia nantoensis. Chem. Pharm. Bull. 2004, 52, 345-349. [CrossRef] [PubMed]

25. Sasamori, H.; Reddy, K.S.; Kirkup, M.P.; Shabanowitz, J.; Lynn, D.G.; Hecht, S.M.; Woode, K.A.; Bryan, R.F.; Campbell, J.; Lynn, W.S.; et al. New cytotoxic principles from Datisca glomerata. J. Chem. Soc. Perkin Trans. 1983, 7, 1333-1347. [CrossRef]

26. Monte, F.J.Q.; Papa, S.M.A.; Kintzinger, J.P.; Braz-Filho, R. Total assignment of ${ }^{1} \mathrm{H}$ and ${ }^{13} \mathrm{C}$ NMR spectra of two isomeric cucurbitane triterpenoids. Magn. Reson. Chem. 2000, 38, 809-812. [CrossRef]

27. Seger, C.; Sturm, S.; Mair, M.-E.; Ellmerer, E.P.; Stuppner, H. Spectral assignments and reference data. ${ }^{1} \mathrm{H}$ and ${ }^{13} \mathrm{C}$ NMR signal assignment of cucurbitacin derivatives from Citrullus colocynthis (L.) Schrader and Ecballium elaterium L. (Cucurbitaceae). Magn. Reson. Chem. 2005, 43, 489-491. [CrossRef]

28. Lavie, D.; Shvo, Y.; Gottlieb, O.R.; Glotter, E. The constituents of Ecballium elaterium L. XVI. Stereochemical problems in the cucurbitacins. J. Org. Chem. 1963, 28, 1790-1795. [CrossRef]

29. Zhang, M.; Ou, Y.-W.; Chen, X.-X.; Cao, Y.; Kuang, Y.; Gong, Z.-Q.; Peng, S.; Chen, Y.-J. Two ent-kaurane diterpenoids from Rubus corchorifolius L.f. Helv. Chim. Acta 2011, 94, 1820-1824. [CrossRef]

30. Tinto, W.F.; Blyden, G.; Reynolds, W.F.; McLean, S. Diterpene and anthraquinone constituents of Glycydendron amazonicum. J. Nat. Prod. 1991, 54, 1127-1130. [CrossRef]

31. Arciniegas, A.; Pérez-Castorena, A.-L.; Nieto-Camacho, A.; Villaseñor, J.L.; de Vivar, A.R. Terpenoids from Melampodium perfoliatum. J. Nat. Prod. 2016, 79, 2780-2787. [CrossRef]

32. Ding, G.; Fei, J.-D.; Wang, J.; Xie, Y.; Li, R.-T.; Gong, N.-B.; Lv, Y.; Yu, C.-Y.; Zou, Z.-M. Fimbriatols A-J, highly oxidized ent-kaurane diterpenoids from traditional Chinese plant Flickingeria fimbriata (B1.) Hawkes. Sci. Rep. 2016, 6, 30560. [CrossRef]

33. Dellagereca, M.; Fiorentino, A.; Monaco, P.; Previtera, L. Polyoxygenated oleanane triterpenes from Hydrocotyle ranunculoides. Phytochemistry 1994, 35, 201-204.

34. Chacón-Morales, P.A.; Santiago-Dugarte, C.; Amaro-Luis, J.M. Unexpected reduction-allylic of hemisynthetic diosphenols from longipinene derivatives. Phytochem. Lett. 2020, 39, 105-110. [CrossRef]

35. Munkombwe, N.M.; Maswabi, T.; Hughes, N.A. Diosphenols from Spirostachys africana. Phytochemistry 1997, 45, 1217-1220. [CrossRef]

36. Ren, Y.-L.; VanSchoiack, A.; Chai, H.-B.; Goetz, M.; Kinghorn, A.D. Cytotoxic barrigenol-like triterpenoids from an extract of Cyrilla racemiflora housed in a repository. J. Nat. Prod. 2015, 78, 2440-2446. [CrossRef] [PubMed]

37. Zhang, G.-J.; Pan, Q.-M.; Zhang, Y.-L.; Liao, H.-B.; Yang, Y.-Q.; Hou, Y.; Liang, D. Coumarinolignoids and taraxerane triterpenoids from Sapium discolor and their inhibitory potential on microglial nitric oxide production. J. Nat. Prod. 2018, 81, 2251-2258. [CrossRef]

38. Gustafson, K.R.; Munro, M.H.G.; Blunt, J.W.; Cardellina II, J.H.; McMahon, J.B.; Gulakowski, R.J.; Cragg, G.M.; Cox, P.A.; Brinen, L.S.; Clardy, J.; et al. HIV inhibitory natural products. 3. diterpenes from Homalanthus acuminatus and Chrysobalanus icaco. Tetrahedron 1991, 47, 4547-4554. [CrossRef]

39. Li, X.; Zhang, D.-Z.; Onad, M.; Konda, Y.; Iguchi, M.; Harigaya, Y. ent-Kauranoid diterpenes from Artemisia sacrorum. J. Nat. Prod. 1990, 53, 657-661. [CrossRef]

40. Chen, Q.; Mao, Q.Q.; Bao, M.; Mou, Y.X.; Fang, C.Y.; Zhao, M.; Jiang, W.; Yu, X.; Wang, C.J.; Dai, L.H.; et al. Spongian diterpenes including one with a rearranged skeleton from the marine sponge Spongai officinalis. J. Nat. Prod. 2019, 82, 1714-1718. [CrossRef]

41. Moffitt, W.; Woodward, R.B.; Moscowitz, A.; Klyne, W.; Djerassi, C. Structure and the optical rotatory dispersion of saturated ketones. J. Am. Chem. Soc. 1961, 83, 4013-4018. [CrossRef] 
42. Zhang, Q.; Lenardo, M.J.; Baltimore, D. 30 years of NF- $\kappa$ B: A blossoming of relevance to human pathobiology. Cell 2017, $168,37-57$. [CrossRef]

43. Sunwoo, J.B.; Chen, Z.; Dong, G.; Yeh, N.; Bancroft, C.C.; Sausville, E.; Adams, J.; Elliott, P.; van Waes, C. Novel proteasome inhibitor PS-341 inhibits activation of nuclear factor- $\kappa \mathrm{B}$, cell suivival, tumor growth, and angiogenesis in squamous cell carcinoma. Clin. Cancer Res. 2001, 7, 1419-1428.

44. He, J.-M.; Chen, S.-C.; Li, R.-P.; Yuan, L.-X.; Bao, J.-M.; Guo, M.-L. Suppresion of nuclear factor-kappa B and mitogen-activated protein kinase signalling pathways by goshonoside-F5 extracted from Rubi Fructus. Int. Immunopharmacol. 2015, 24, 182-190. [CrossRef]

45. Han, B.; Chen, J.; Yu, Y.-Q.; Cao, Y.-B.; Jiang, Y.-Y. Anti-fungal activity of Rubus chingii extract combined with fluconazole against fluconazole-resistant Candida albicans. Microbiol. Immunol. 2016, 60, 82-92. [CrossRef]

46. Pu, D.B.; Li, X.N.; Lin, J.; Zhang, R.H.; Luo, T.; Wang, Y.; Gao, J.B.; Zeb, M.A.; Zhang, X.J.; Li, X.L.; et al. Triterpenoids from Ganoderma gibbosum: A class of sensitizers of FLC-resistant Candida albicans to fluconazole. J. Nat. Prod. 2019, 82, $2067-2077$. [CrossRef]

47. Peng, Y.-M.; Zheng, J.-B.; Zhou, Y.-B.; Li, J. Characterization of a novel curcumin analog P1 as potent inhibitor of the NF- $\kappa$ B signaling pathway with distinct mechanisms. Acta Pharmacol. Sin. 2013, 34, 939-950. [CrossRef] [PubMed]

48. Clinical and Laboratory Standards Institute. M27-A3 Reference Method for Broth Dilution Anti-fungal Susceptibility Testing of Yeats. In Approved Standard, 3rd ed.; Clinical and Laboratory Standards Institute: Wayne, PA, USA, 2008.

49. He, Y.-Q.; Jin, S.-S.; Ma, Z.-Y.; Zhao, J.; Yang, Q.; Zhang, Q.; Zhao, Y.-J.; Yao, B.-H. The anti-oxidant compounds isolated from the fruits of Chinese wild raspberry Rubus chingii Hu. Nat. Prod. Res. 2020, 34, 872-875. [CrossRef]

50. Deng, Y.H.; Tianasoa-Ramamonjy, M.; Snyder, J.K. Remangilone D, a new bisnoroleanane triterpene, and a new flavone from Physena madagascariensis. Z. Naturforsch. B 2001, 56, 1079-1083. [CrossRef]

51. Deng, Y.H.; Jiang, T.-Y.; Sheng, S.J.; Tianasoa-Ramamonjy, M.; Snyder, J.K. Remangilones A-C, new cytotoxic triterpenes from Physena madagascariensis. J. Nat. Prod. 1999, 62, 471-476. [CrossRef] [PubMed]

52. Duan, H.Q.; Takaishi, Y.; Momota, H.; Ohmoto, Y.; Taki, T.; Tori, M.; Takaoka, S.; Jia, Y.F.; Li, D. Immunosuppressive terpenoids from extracts of Tripterygium wilfordii. Tetrahedron 2001, 57, 8413-8424. [CrossRef]

53. Tian, Y.-N.; Li, B.-L.; Hu, J.-J.; Xie, J.-D.; Xiao, W.-J.; Nie, L.-H.; Wu, J.-W. Rosanortriterpenes A-B, two new nortriterpenes from the fruits of Rosa laevigata var. leiocapus. Nat. Prod. Res. 2019. [CrossRef] [PubMed]

54. Huang, F.X.; Lin, X.H.; He, W.N.; Song, W.; Ye, M.; Yang, W.Z.; Guo, D.A. Two new oxidation products obtained from the biotransformation of asiatic acis by the fungus Fusarium avenaceum AS 3.4594. J. Asian Nat. Prod. Res. 2012, 14, 1039-1045. [CrossRef] [PubMed]

55. Nhiem, N.X.; Yen, P.H.; Nguyen, T.T.N.; Quang, T.H.; Kiem, P.V.; Minh, C.V.; Tai, B.H.; Cuong, N.X.; Song, S.B.; Kim, Y.H. Inhibition of nuclear transcription factor-kappa B and activation of peroxisome proliferator-activated receptors in HepG2 cells by cucurbatane-type triterpene glycosides from Momordica charantia. J. Med. Food 2012, 15, 369-377. [CrossRef] [PubMed] 